\title{
A New Method for the Evaluation of Well Rehabilitation from the Early Portion of a Pumping Test
}

\author{
Daniel Kahuda and Pavel Pech * (D) \\ Faculty of Environmental Sciences, Czech University of Life Sciences Prague, Kamýcká 129, \\ 16500 Praha-Suchdol, Czech Republic; kahuda@fzp.czu.cz \\ * Correspondence: pech@fzp.czu.cz; Tel.: +420-724-077-070
}

Received: 16 January 2020; Accepted: 28 February 2020; Published: 8 March 2020

\begin{abstract}
This study analyzes the unsteady groundwater flow to a real well (with wellbore storage and the skin effect) that fully penetrates the confined aquifer. The well is located within an infinite system, so the effect of boundaries is not considered. The Laplace-domain solution for a partial differential equation is used to describe the unsteady radial flow to a well. The real space solution is obtained by means of the numerical inversion of the Laplace transform using the Stehfest algorithm 368. When wellbore storage and the skin effect dominate pumping test data and testing is conducted for long enough, two semilogarithmic straight lines are normally obtained. The first straight line can be identified readily as the line of the maximum slope. The correlation of the dimensionless drawdown for the intersection time of this first straight line, with the log time axis as a function of the dimensionless wellbore storage and the skin factor, is shown. This paper presents a new method for evaluating the skin factor from the early portion of a pumping test. This method can be used to evaluate the skin factor when the well-known Cooper-Jacob semilogarithmic method cannot be used due to the second straight line not being achieved in the semilogarithmic graph drawdown vs. the log time. A field example is presented to evaluate the well rehabilitation in Veselí nad Lužnicí by means of the new correlation.
\end{abstract}

Keywords: groundwater; unsteady flow; pumping test; Laplace transform; well rehabilitation; wellbore storage; skin effect

\section{Introduction}

For groundwater, a pumping test is a field test in which a well is pumped at a constant rate, and "drawdown" (the difference between the height of water at time $=0$ and the height of water in actual time) is measured and analyzed. In petroleum engineering, the "drawdown" test is a test with a constant rate, $q$, that measures the pressure response. Pumping tests are widely used for the evaluation of aquifer hydraulic parameters, including transmissivity, $T$, and the storage coefficient of the aquifer, $S$. These tests have wide applications in the field of petroleum engineering and groundwater hydraulics based on the Theis analytical solution [1] for drawdown at the well caused by pumping at a constant rate from a full well in a homogeneous, uniform, and confined aquifer with a negligible well radius, as well as when the flow to the well is not influenced by the outer boundaries and additional resistances in a well and in its surroundings. The most commonly used method in well testing derived from the Theis solution is based on a semilogarithmic presentation of the drawdown at the well vs. the logarithm of pumping time. This method was introduced by Cooper and Jacob for drawdown tests [2]. The Cooper-Jacob semilogarithmic method is a more restricted version of the Theis well function and describes the drawdown at an "ideal well", which means a well with a negligible well radius and 
without additional types of resistance in the well and its surroundings. There has been a continuous development of analytical models and well-testing procedures for petroleum and groundwater areas. This testing is reflected in the many books published on petroleum engineering and groundwater hydraulics [3-9].

In reality, the radius of a pumping well and the additional resistance in a well and its surroundings are non-zero; thus, these assumptions may lead to some errors in the data analyses $[10,11]$. Under the assumption of a finite radius for the pumping well $\left(r_{w} \neq 0\right)$, the "wellbore storage effect" (the volume of water inside a wellbore), and its influence on pumping test evaluations, was published by Papadopulos-Cooper [12,13], who presented a close form solution for the drawdown in a large-diameter well, while also accounting for the effect of wellbore storage.

Other authors have studied this phenomenon and its influence on well drawdown in petroleum and groundwater areas during early periods of pumping [14-19]. Testing the wellbore storage during the early period of pumping has an influence on well drawdown [20]; neglecting its effects could result in overestimating the storage coefficient from, for example, the type curve method. Additional resistance in the pumping well and in the damaged zone near the well induces extra a head loss known as the skin effect. There are many factors that cause the skin effect, including physical, chemical, and biological processes acting on the well and its immediate surroundings. These processes include the invasion of mud during the drilling process, incomplete perforations, fine material migration near the well, and others. The skin effect is presented by a dimensionless skin factor, denoted here as $S_{F}$. This factor is used to characterize all additional resistance in the pumping well and in the surrounding well: the larger the skin factor, the greater the drawdown loss. The permeability damage to aquifers caused by drilling operations with drilling mud ranges from a few millimeters to several centimeters and during ageing (exploitation) of the well, the permeability damage is caused by physical, chemical, and biological processes; moreover, the skin zone can reach several meters [11]. The additional resistance (the skin effect) and finite volume of a wellbore (wellbore storage) are the two main factors that influence the pumping test data measured at a well. The drawdown caused by additional resistance (the skin effect) was introduced, for the first time in petroleum engineering, by van Everdingen and Hurst [21-23]. Since then, many authors in the fields of petroleum and groundwater hydraulics have published articles focused on the problem of the influence of the skin effect and wellbore storage on the measured values of the real drawdown or pressure drops in a well [24-31]. In 1970, Agarwal [32] presented a fundamental study of the importance of wellbore storage and skin on the short-time transient flow and introduced the idea of log-log type curve matching to analyze pressure data for a well dominated by the skin effect and wellbore storage. Subsequently, many other type curve methods have been presented. A type curve method is a graphical representation of the theoretical solution to flow equations. A type curve analysis consists of finding the theoretical type curve that "matches" the actual response from a test well and reservoir when subjected to changes in production rates or pressures. These tests are usually presented in terms of dimensionless pressure, dimensionless time, dimensionless radius, and dimensionless wellbore storage rather than real variables. The reservoir parameters (such as permeability) and well parameters (for example, skin) can be evaluated from the dimensionless parameters defining that type of curve [33-43]. Among the many type curve methods, two are mentioned further: Gringarten type curves [36] and the pressure derivative method [3]. There are three dimensionless groups that Gringarten uses when developing a type curve: dimensionless pressure, the ratio of dimensionless time and dimensionless wellbore storage, and the dimensionless characterization group, $C_{D} e^{2 S}$. All type curve solutions are obtained for the drawdown solutions. The Gringarten type curve can also be used for a gas system, but the dimensionless pressure drop and time must be redefined. Bourdet defined the pressure derivative as the derivative of dimensionless pressure with respect to dimensionless time. From a mathematical point of view, the derivative of pressure with respect to time is even more fundamental than pressure itself, as the pressure's partial derivative appears directly in the diffusivity equation describing the transient fluid flow in an aquifer system. Bourdet and his co-authors proposed that flow regimes can have clear characteristic shapes 
if the "pressure derivative", rather than pressure, is plotted against time in the log-log coordinates. Since the introduction of the pressure derivative type curve, well-testing analysis has been greatly enhanced. The use of pressure derivative type curves offers the following advantages: flow regimes have clear characteristic shapes on the derivative plot, and the derivative plots are able to be displayed in a single graph with many separate characteristics that would otherwise require different plots. This derivative approach improves the definition of the analysis plots and, therefore, the quality of the interpretation and quantitative estimation of aquifer properties becomes more reliable. By using this method, interpretation is not only simple but also more accurate [10]. Interesting methods for evaluating the transmissivity, wellbore storage, and skin factor from the early-time portion of pumping test data was published in [31]. If the skin effect and wellbore storage dominate the drawdown data, and if testing has been conducted long enough, two semilogarithmic straight lines are normally obtained. For an infinite aquifer (where the boundary effect does not interfere with the pumping test data), the second straight line is the appropriate Cooper-Jacob straight line. The first straight line is the line of the maximum slope and is typical for early time points. The slope of this straight line is affected by wellbore storage and skin effect. The new method for evaluating the skin factor in a single well fully penetrating the confined aquifer from the early portion of a pumping test is derived under the following assumptions: non zero additional resistance at the pumping well, a finite well radius (wellbore storage effect), and the well being situated in an infinite aquifer (where no observation well is available). The solution of the general partial differential equation of a symmetrical radial water flow to a well in Laplace space was used [15]. The Laplace transform was numerically inverted by the Stehfest algorithm 368 [44], which is very often used in groundwater flow problems [32,43,45-50]. Here, we present a correlation of the dimensionless drawdown in dimensionless time for the intersection the first straight-line with the horizontal axis (log time) in a semilogarithmic graph as a function of the dimensionless wellbore storage constant and skin factor. Using this correlation, a new procedure for evaluating the skin factor is presented. This new method to evaluate the skin factor from the early portion of a pumping test is not intended to replace any of the approaches presented in the literature but rather to supplement them.

\section{Materials and Methods}

In deriving a new method for evaluating the coefficient of additional resistance (skin factor, $S_{F}$ ) from the early part of a pumping test, dimensionless parameters were used, as is commonly done in petroleum engineering $[4,5,32,50]$. Dimensionless parameters simplify the solution of hydrodynamic tests on wells by including parameters such as hydraulic conductivity, transmissivity, aquifer storage coefficient, time, well radius, etc. into the dimensionless parameters. By introducing dimensionless parameters, we reduce the number of unknowns, ensuring that the solution is independent of the unit systems being used. To solve the groundwater flow to the well, these dimensionless parameters were defined as follows $[4,48,49]$ :

- Dimensionless drawdown at any distance from the well being pumped:

$$
s_{D}\left(r_{D}, t_{D}\right)=\frac{2 \pi T}{Q}(H-h(r, t))
$$

where $Q$ is the pumping rate $\left[\mathrm{L}^{3} \mathrm{~T}^{-1}\right] ; T$ is the transmissivity $\left[\mathrm{L}^{2} \mathrm{~T}^{-1}\right] ; H$ is the hydraulic head within the radius of well influence [L] and $h(r, t)$ is the hydraulic head at time $t$ and at a distance $r$ from the well axis [L]; and $r_{D}$ is dimensionless radius and $t_{D}$ is dimensionless time.

- Dimensionless drawdown in the pumped well:

$$
s_{w D}\left(r_{D}=1, t_{D}\right)=\frac{2 \pi T}{Q}\left(H-h_{w}(t)\right)
$$


where $h_{W}$ is the hydraulic head in the well at time $t[\mathrm{~L}]$, and $H$ is the initial hydraulic head in time equal zero [L].

- Dimensionless time:

$$
t_{D}=\frac{T t}{r_{w}^{2} S}
$$

where $r_{w}$ is the well radius [L]; $S$ is the storage coefficient (aquifer storativity) [-]; and $t$ is time [T].

- Dimensionless intersection time:

$$
t_{D}^{*}=\frac{T t^{*}}{r_{w}^{2} S}
$$

where $t^{*}$ is time where the "first semilogarithmic straight line" intersects the horizontal axis $\log t_{D}$

- Dimensionless radius:

$$
r_{D}=\frac{r}{r_{w}}
$$

where $r$ is the radial distance from the well pumped axis [L], and $r_{w}$ is the well radius [L].

- Dimensionless coefficient of wellbore storage:

$$
C_{D}=\frac{C}{2 \pi r_{w}^{2} S}
$$

where $C$ is the "unit factor" of the wellbore storage $\left[\mathrm{L}^{2}\right]$ defined in [20].

- Dimensional drawdown for the intersection time $t^{*}$ of the "first straight line" with the horizontal axis, $\log t_{D}$ :

$$
s_{D}^{*}=\frac{2 \pi T}{Q} s^{*}
$$

where $s^{*}$ is the drawdown at the point of intersection between the "first straight line" segment with the time axis [L]

One of the criteria divides wells into two groups. The first are ideal wells, and the second are real wells. An ideal well is a well whose radius is infinitely small $\left(r_{w} \rightarrow 0\right)$ and whose additional resistance in the well and its immediate vicinity is zero. In this article, we will not focus on ideal wells and the evaluation of hydrodynamic tests on these wells. The basic literature dealing with the evaluation of hydrodynamic tests on ideal wells includes $[3-6,8,9,50]$.

\subsection{Real Wells}

\section{- Wellbore Storage}

The first assumption that distinguishes real wells from ideal wells is the effect of the well's own volume (wellbore storage) on the pumping (build-up) tests-i.e., the well radius is not negligible and must be considered in an evaluation. At the beginning of the hydrodynamic tests on the well (pumping and build-up), when the water is pumped from the wellbore's own volume or the well is filled after stop pumping, this phenomenon affects the shape of the drawdown curve as a function of time until the pumping rate (or inflow into well) $Q_{w s}$ from the well volume is equal to zero. In more detail, Papadopulos and Cooper [12] (for groundwater) and Ramey (for petroleum engineering) [20] described and discussed the impact of the well volume on the pumping test during the first part of a pumping (build-up) test. The effect of the well radius (wellbore storage) on dimensionless drawdown gradually diminishes (Figure 1) as the time of pumping increases. Figure 1 shows the relationship between the pumped amount from the well volume, $Q_{w s}$, and the inflow rate from the aquifer, $Q_{a q}$, as a function of time. 


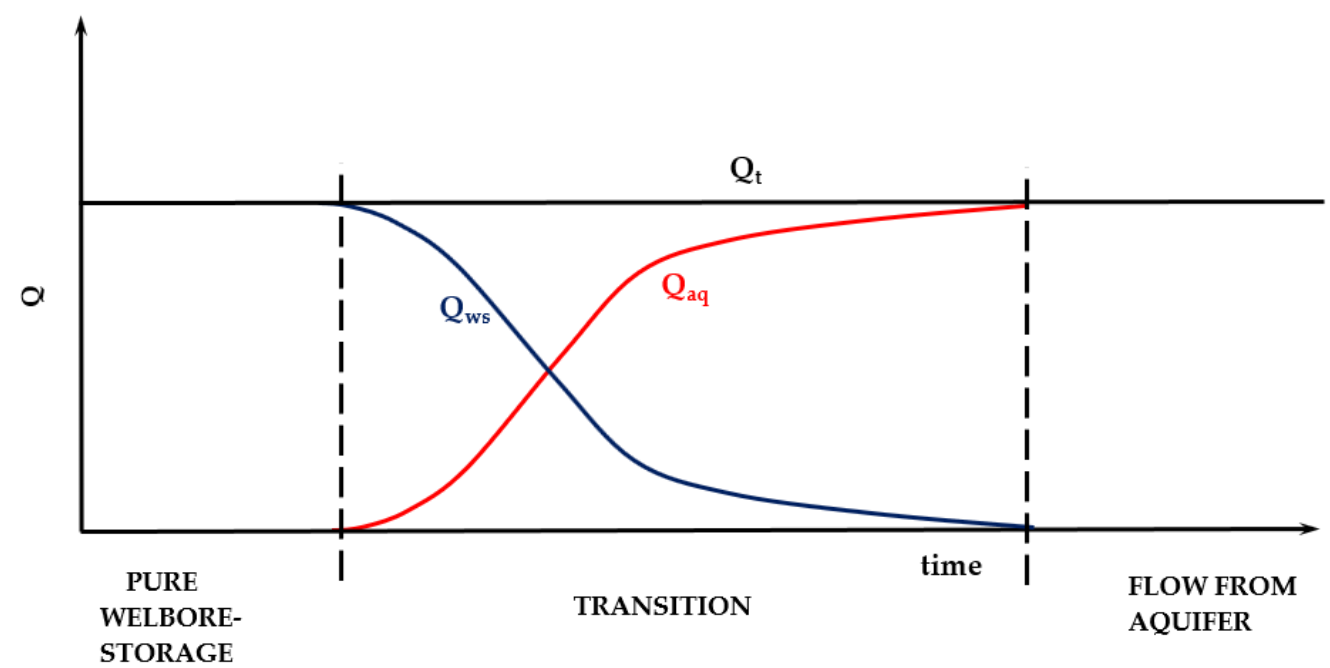

Figure 1. Pumping rate from wellbore storage, $Q_{w s}$, and groundwater inflow rate from aquifer, $Q_{a q}$, as a function of time.

Ramey $[15,16]$ states that, for the start of a pumping test (from several seconds to approximately several minutes, depending on the well diameter and pumping rate), a straight line with the "unit slope" can be found in the pumping test graph ( $\log s$ vs. $\log t$ ) (Figure 2) (i.e., the deviation of the straight line from the horizontal axis is $45^{\circ}$ ). The "straight line" with the "unit slope" lasts until all the water is pumped from the well's volume. According to [16], we can determine the unit factor of the wellbore storage, $C$, from the following equation:

$$
C=Q \frac{t_{B}}{s_{B}}
$$

where $t_{B}$ is time for the arbitrarily selected point $B$ on the "unit" slope line (Figure 2) [T], and $s_{B}$ is the drawdown at time $t_{B}[\mathrm{~L}]$.

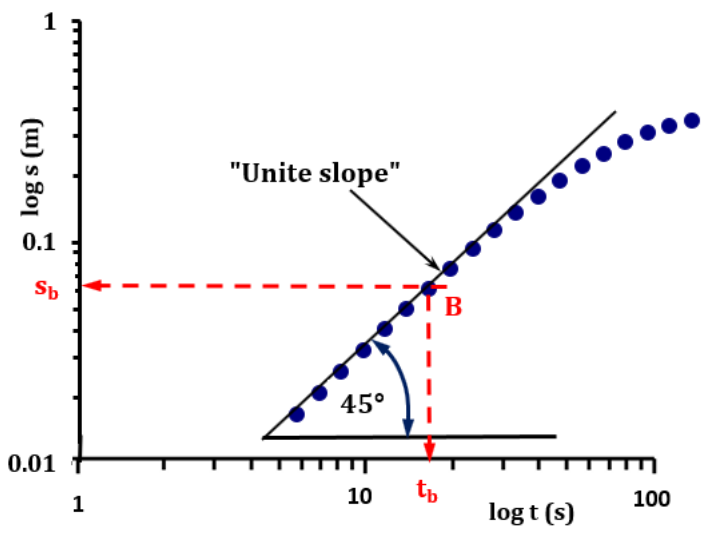

Figure 2. Graph $\log s$ vs. $\log t$ at the beginning of the pumping test when the water is pumped only from the wellbore's own volume.

Using Equation (6), the dimensionless coefficient of wellbore storage, which is one of the basic characteristics of the initial pumping test section, is determined. This parameter affects the shape of the drawdown curve during the pumping test during the time before reaching Cooper-Jacob's 
semilogarithmic straight line, when the effect of water in the well volume disappears completely. The dimensionless storage coefficient can be expressed from Equation (6) in the following form:

$$
C_{D}=\frac{Q \frac{t_{B}}{s_{B}}}{2 \pi r_{w}^{2} S}
$$

\section{- Additional Resistance (Skin Effect)}

The drawdown of the water level in a "real" well depends on the resistance of the aquifer and the so called "additional losses" or resistance generated in the well, on its walls, and in the vicinity of the well. The term "additional resistance" refers to the sum of the phenomena that result in deviations of the measured values of water drawdown in a "real" well compared to the theoretical drawdown obtained under the assumption of an "ideal" model of water flow to a complete well (this is the case for additional resistance, and the actual borehole volume will not be reflected in the course of the inflow test (i.e., the reduction in this volume is not affected). The drawdown in the water level (or increase) measured at the pumping well (or recharge well) is, then, greater than the calculated drawdown (or increase) in the borehole, which would cause a hydraulic intervention through a hydraulically perfect well without this additional resistance. Additional resistance in the well and its surroundings increase in the following ways [51]:

(a) By the clogging of pores $\left(s_{1}\right)$ with, e.g., a fine material, which reduces the flow rate of the porous environment or disrupts the original internal structure of the porous environment in the vicinity of the wellbore during digging and equipping (it decreases the porous environment's permeability) in rotary drilling, the result of which is so-called sludge bark; in the case of impact drilling, the porous environment in the vicinity of the well is compacted, thereby reducing throughput [52-54].

(b) Through a reduction in the wellbore wall cross-section $\left(s_{2}\right)$ for the water inflow where the borehole wall is formed by a filter, perforated casing, etc., by trapping rock particles or backfill in filter openings, including chemical incrustation and the blockage of filter openings by microorganisms and bacteria [55-57].

(c) Via the friction $\left(s_{3}\right)$ of water on the borehole walls and its internal friction (this group also includes the additional resistance arising from the turbulent flow regime of the water inside the borehole and the turbulent flow in the aquifer, especially in the vicinity of the pumping well.

(d) Where appropriate, other types of additional resistance occur.

The drawdown due to the effect of additional resistance is expressed (Figure 3) as:

$$
s_{\text {skin }}=s_{1}+s_{2}+s_{3}+\ldots+s_{n} \text {; so we can write } s_{\text {skin }}=\sum_{i=1}^{n} s_{i}
$$

where $s_{\text {skin }}$ is the total additional drawdown in the well ("the skin drawdown") caused by the additional resistance in the well and its immediate vicinity (in the so-called skin zone). The separation of the individual additional types of resistance involved in the skin effect is very problematic; therefore, the total dimensionless additional resistance coefficient, $S_{F}$ (in the petroleum literature, referred to as the skin factor), is commonly used to express the total additional resistance. The total drawdown of the water level measured in the borehole during the pumping test can be expressed (when neglecting the additional resistance resulting from the turbulent flow regime) by the relation:

$$
s_{w}=s_{t e}+s_{s k i n}
$$

where $s_{w}$ is the total drawdown in the pumping well [L]; $s_{t e}$ is the theoretical drawdown of the water level in an "ideal" well (zero additional resistances) [L]; and $s_{\text {skin }}$ is the additional drawdown of water in the wellbore due to additional resistance [L]. 


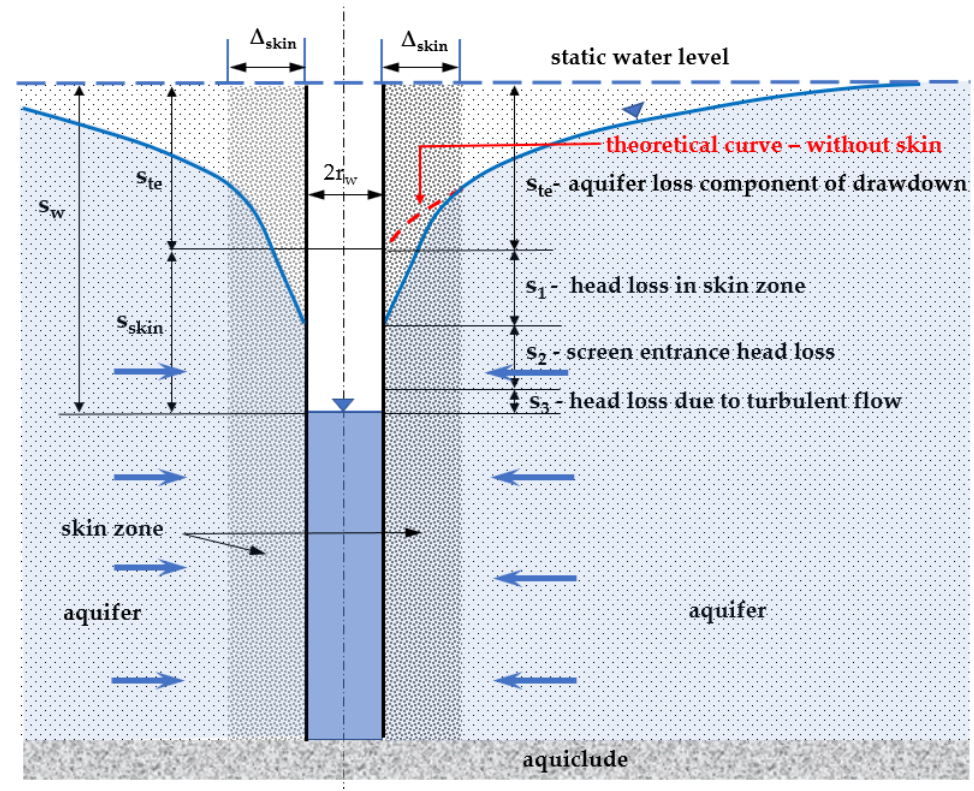

Figure 3. Real well: various head losses in a pumped well.

Neglecting the portion of the drawdown that follows from the turbulent flow regime, $s_{3}$ (its share in the total additional drawdown is negligible), the magnitude of the additional drawdown caused by additional resistance is dependent on the pumping rate, $Q$, with the linear relationship [21]

$$
s_{\text {skin }}=\frac{Q}{2 \pi T} S_{F}
$$

where $S_{F}$ is the dimensionless coefficient of additional resistance (skin factor) [-]; and $s_{s k i n}$ is the drawdown caused by additional resistance [L].

The effect of additional resistance will be included in the total drawdown on the "real" well when the flow is at a tight level.

(a) For the steady flow [21], we can write:

$$
s_{w}=\frac{Q}{2 \pi T}\left(\ln \frac{R}{r_{w}}+S_{F}\right)
$$

where $R$ is the radius of well influence $[\mathrm{L}] ; r_{w}$ is the wellbore radius [L]; and $S_{F}$ is the coefficient of additional resistance (skin factor) [-].

(b) The unsteady flow regime (using the Cooper-Jacob semi-logarithmic method because this part no longer shows the influence of wellbore storage) can be expressed as:

$$
s_{w}=\frac{Q}{4 \pi T}\left(\ln 2.246 t_{D}+2 S_{F}\right) .
$$

After converting the natural logarithm to a normal logarithm, we obtain the following equation:

$$
s_{w}=\frac{2.303 Q}{4 \pi T}\left(\log \left(2.246 t_{D}\right)+2 S_{F}\right) .
$$


If the Cooper-Jacob semilogarithmic straight line is reached in the semilogarithmic graph of the pumping test, we can use Equation (15) to evaluate the coefficient of additional resistance. After expressing $S_{F}$ and adjusting, we obtain:

$$
S_{F}=\frac{2 \pi T s_{w}}{Q}-\frac{1}{2}\left(\log t+\log \frac{T}{r_{w}^{2} S}+0.8091\right) .
$$

\subsection{Deriving the New Correlation to Evaluate the Skin Factor from the First Straight Line}

For a real well, we refer to a wellbore and account for the existence of additional resistance in the well and in its immediate surroundings (as defined above) in comparison with an ideal wellbore. In the initial portion of the hydrodynamic test, we also include the influence of the volume of wellbore in the calculations. To derive the new correlation, the equation of radially symmetrical groundwater flow to the wellbore under an unsteady state regime was used, transformed into dimensionless parameters with the initial and boundary conditions defined according to the petroleum engineering standards of Agarwal et al. [32]. The basic equation for the radial-symmetric flow of groundwater to the wellbore has a similar shape (e.g., $[7,26,32,58])$ :

$$
\frac{\partial^{2} s_{D}}{\partial r_{D}^{2}}+\frac{1}{r_{D}} \frac{\partial s_{D}}{\partial r_{D}}=\frac{\partial s_{D}}{\partial t_{D}}
$$

The assumptions for solving Equation (17) are the same as those for the Theis solution for an ideal well. In a flow in a confined aquifer to a complete well, the following parameters are true:

- The gravitational forces are negligible;

- A constant density and viscosity of water;

- The aquifer has an infinite areal extent;

- The pumping well penetrates the full thickness of the aquifer;

- The flow to the pumping well is horizontal;

- The flow is unsteady;

- The diameter of a pumping well is very small (negligible), allowing the storage in the well to be neglected;

- $\quad$ The well is pumped with constant rate $Q$;

- The aquifer is horizontal and bounded on the bottom and top by impermeable layers (a confined aquifer);

- The aquifer flow to the pumped well is radial and laminar, so Darcy's law is applied;

- The confined aquifer is homogeneous and isotropic;

- The height of an aquifer (where the flow to the well is constant and has a size b transmissivity, T, and storability (aquifer storage), $S$ ) is constant over time and space;

- The water supply from the aquifer to the well changes during the pumping test from $Q_{a q}=0$ to the final inflow, $Q_{a q}=Q=$ const.;

- Before pumping begins (i.e., for $t=0$ ), the hydraulic head is constant in all points of the aquatic environment and equals $\mathrm{H}$; this also applies to the water level at a well.

Moreover, it is assumed (for a "real" well) that:

- The well possesses its final volume, and, at the beginning of pumping, the effect of the water volume in the wellbore influences the drawdown and must be considered;

- The wellbore storage coefficient is constant and does not change during pumping;

- The influence of additional resistance occurring in the wellbore itself and in its immediate vicinity is considered (the width of the perpendicular zone can reach up to about 2-7 $\mathrm{m}$ ). 
The initial and boundary conditions (in dimensionless parameters) for a real well have the shape [32] of:

$$
\begin{gathered}
s_{D}\left(r_{D}, 0\right)=0 \\
s_{D}\left(r_{D}, t_{D}\right)=0 \text { for } r_{D} \rightarrow \infty,
\end{gathered}
$$

for additional resistance,

$$
s_{w D}=s_{D}+\left(r_{D} \frac{\partial s_{D}}{\partial r_{D}}\right)_{r_{w}} s_{F}
$$

and for wellbore storage,

$$
C_{D} \frac{d s_{D}}{d t_{D}}-\left(r_{D} \frac{\partial s_{D}}{\partial r_{D}}\right)=1
$$

To solve basic Equation (17) with the initial and boundary conditions (Equations (18)-(21)), a one-sided Laplace transform was used to convert the partial differential equation in the dimensionless parameters (17) to a normal differential equation. We used a transformation function that provides a shape for the solved case in the following form [32]:

$$
F(p)=\mathcal{L}\left(f\left(t_{D}\right)\right)=\int_{0}^{\infty} f\left(t_{D}\right) e^{-p t_{D}} d t_{D}
$$

This is an integral transformation with kernel $\exp \left(-\mathrm{pt}_{\mathrm{D}}\right)$, where $p$ is a complex variable; and $F(p)$ is the image of the given object, $f\left(t_{D}\right)$. In Laplace space, the solution of Equation (17) has the following form:

$$
\overline{s_{D}}=\frac{K_{0}\left(p^{\frac{1}{2}}\right)+S_{F} p^{\frac{1}{2}} K_{1}\left(p^{\frac{1}{2}}\right)}{p\left[p^{\frac{1}{2}} K_{1}\left(p^{\frac{1}{2}}\right)+C_{D} p^{\frac{1}{2}}\left(K_{0}\left(p^{\frac{1}{2}}\right)+S_{F} p^{\frac{1}{2}} K_{1}\left(p^{\frac{1}{2}}\right)\right)\right]}
$$

where $\left(\overline{s_{D}}\right)$ is the solution of the dimensionless drawdown for $r_{D}$ and $t_{D}$ in Laplace space; $p$ is a complex variable; $K_{0}$ is the modified Bessel function of the second kind with an order of zero (imaginary argument); $K_{1}$ is the modified Bessel function of the second kind with an order of one (imaginary argument); $C_{D}$ is the dimensionless coefficient of wellbore storage; and $S_{F}$ is the dimensionless coefficient of additional resistance (skin factor). When evaluating $K_{0}$ and $K_{1}$, dimensionless drawdown values were taken from [59]. For the inverse Laplace transformation, the Stehfest algorithm 368 [44] was used, which is very often used in petroleum engineering and groundwater hydraulics $[7,60]$. From [7] we can obtain:

$$
f\left(t_{D}\right)=\sum_{j=1}^{\frac{n}{2}} X_{j}\left(\frac{n}{2}\right) P_{\left(\frac{n}{2}+1-j\right)}
$$

where,

$$
\begin{gathered}
X_{j}\left(\frac{n}{2}\right)=\frac{(-1)^{(j-1)}}{\left(\frac{n}{2}\right) !}\left(\begin{array}{c}
\frac{n}{2} \\
j
\end{array}\right) j\left(\frac{n}{2}+1-j\right)^{\left(\frac{n}{2}-1\right)} \\
P_{n}=\frac{\ln 2}{t_{D}} \frac{(2 n) !}{n !(n-1) !} \sum_{i=0}^{n}\left(\begin{array}{c}
n \\
i
\end{array}\right)(-1)^{i} F\left((n+i) \frac{\ln 2}{t_{D}}\right) .
\end{gathered}
$$

To evaluate $s_{D}$ from Equation (23) by means of Equations (24)-(26), value $\mathrm{n}$ is 10, as used in [7]. Stehfest's algorithm 368 was used to calculate the dimensionless drawdown, which depends on the skin factor and wellbore storage. Calculations were done for skin factor $S_{F}=0,2,4,6,8,10,12.5,15,20$, $30,35,40,50$, and for dimensionless wellbore storage, $C_{D}=10,50,5 \times 10^{2}, 1 \times 10^{3}, 5 \times 10^{3}, 1 \times 10^{4}$, $5 \times 10^{4}, 1 \times 10^{5}, 5 \times 10^{5}, 1 \times 10^{6}, 5 \times 10^{6}$, and $1 \times 10^{7}$. For clarity of the graphs, Figure 4 illustrates the dependencies of $s_{D}$ on $\log t_{D}$ for $C_{D}=1 \times 10^{2}, 1 \times 10^{4}, 1 \times 10^{7}$, and $S_{F}=0,10,20,30$, and 40 . 


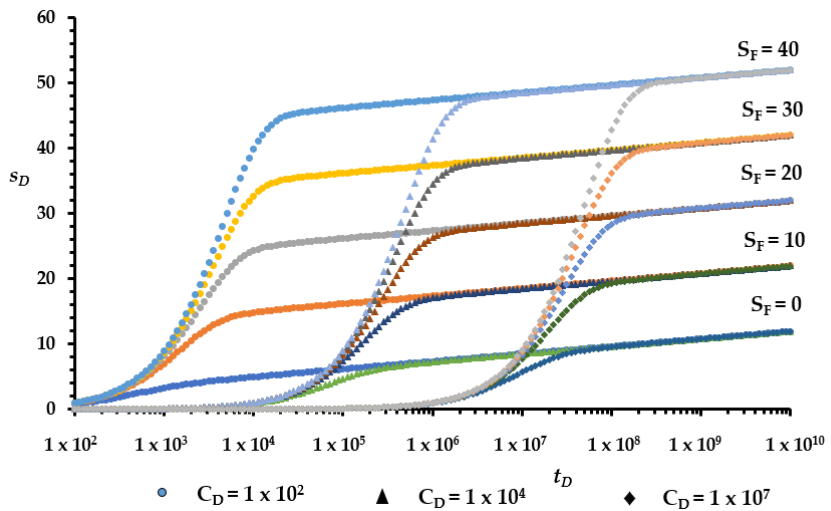

Figure 4. Demonstration of dimensionless drawdown $s_{D}$ vs. $\log t_{D}$ (for the selected values, $S_{F}$ and $C_{D}$ ).

As shown in Figure 4 and also in Figure 5 (see also [31]), the graphs always present two straight lines. The "first straight line" segment appears in the graph in its initial part, i.e., at the time when the drawdown at the well (at a constant rate $Q$ ) is affected both by the additional resistance on the well and by its vicinity and the well volume (wellbore storage). The slope of the first straight line section is denoted $i_{Z D}$. The "second straight line" in the semilogarithmic plot of $s_{D}$ vs. $\log t_{D}$ appears only in the late periods of the graph and corresponds to the area that can be evaluated by the Cooper-Jacob semilogarithmic approximation [2]. The same two straight lines can be observed in field pumping tests on the semilogarithmic graph drawdown of $s$ vs. $\log t$ [31].

Based on Figure 4, in the early-portion of the pumping test, which is influenced by both factors (skin effect and wellbore storage), by increasing the skin factor, the slope of the first straight line $i_{Z D}$ section increases; also, if the dimensionless wellbore storage, $C_{D}$, increases then the curves $s_{D}$ vs. $\log$ $t_{D}$ are moved in a positive direction (i.e., to the right).

To evaluate the additional resistances from the early-portion of the pumping test (until the Cooper-Jacob semi-logarithmic section is unable to be reached), a drawdown value, $s_{D}{ }^{*}$, for dimensionless time $t_{D}{ }^{*}$ was selected, which is the time of the intersection of the first straight line with the timeline axis (Figure 5). Dimensionless drawdown $s_{D}{ }^{*}$ depends on the dimensionless wellbore storage $C_{D}$ and the coefficient of additional resistance, $S_{F}$. In this way, we can find a correlation between the dimensionless drawdown, $\mathrm{s}_{\mathrm{D}}{ }^{*}$; the dimensionless wellbore storage, $C_{D}$; and the skin factor, $S_{F}$.

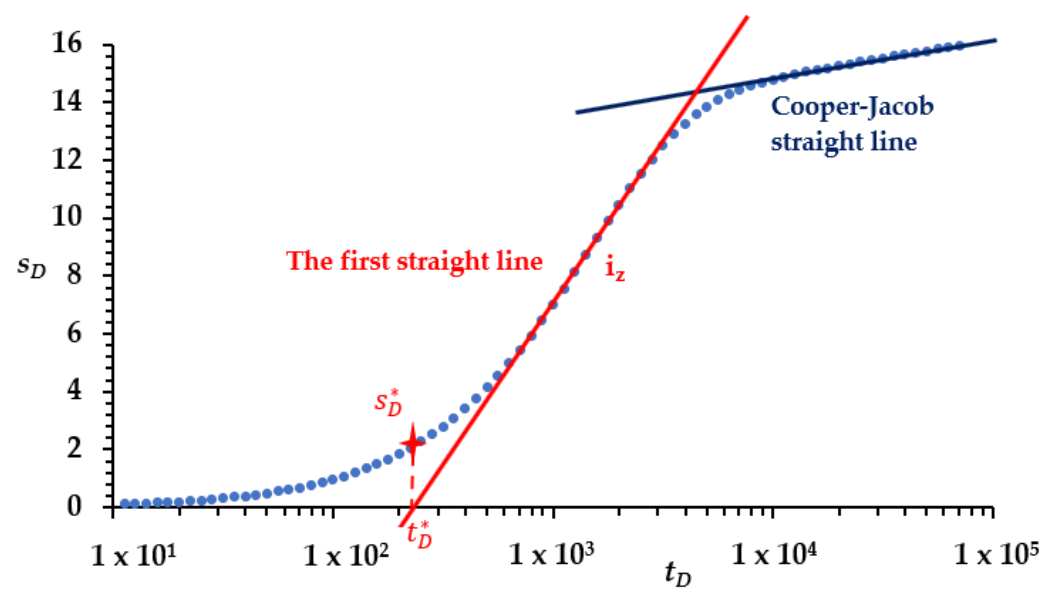

Figure 5. Semilogarithmic graph $s_{D}$ vs. $\log t_{D}$ with two straight lines.

\section{Results}

We evaluated the dimensionless drawdown values $s_{D}{ }^{*}$ for the dimensionless wellbore storage, $C_{D}=1 \times 10^{2}, 5 \times 10^{2}, 1 \times 10^{3}, 5 \times 10^{3}, 1 \times 10^{4}, 5 \times 10^{4}, 1 \times 10^{5}, 5 \times 10^{5}, 1 \times 10^{6}, 5 \times 10^{6}$, and $1 \times 10^{7}$ 
and for the dimensionless skin factor $S_{F}=1,2,4,6,8,10,15,20,25,30,35,40,45,50,60,70,80,90$, and 100 (see Table 1).

Table 1. Dimensionless drawdown, $s_{D}$, for the selected skin factors, $S_{F}$ and the dimensionless wellbore storage, $C_{D}$.

\begin{tabular}{|c|c|c|c|c|c|c|c|c|c|c|}
\hline $\mathrm{S}_{\mathrm{F}} \quad \mathrm{C}_{\mathrm{D}}$ & $1 \times 10^{2}$ & $5 \times 10^{2}$ & $1 \times 10^{3}$ & $5 \times 10^{3}$ & $1 \times 10^{4}$ & $5 \times 10^{4}$ & $1 \times 10^{5}$ & $5 \times 10^{5}$ & $1 \times 10^{6}$ & $5 \times 10^{6}$ \\
\hline 0 & 0.6 & 0.73 & 0.79 & 0.93 & 0.99 & 1.13 & 1.19 & 1.33 & 1.39 & 1.52 \\
\hline 2 & 0.94 & 1.08 & 1.14 & 1.28 & 1.33 & 1.47 & 1.53 & 1.67 & 1.73 & 1.87 \\
\hline 4 & 1.28 & 1.42 & 1.48 & 1.62 & 1.67 & 1.82 & 1.86 & 2.01 & 2.07 & 2.20 \\
\hline 6 & 1.62 & 1.76 & 1.81 & 1.96 & 2.02 & 2.15 & 2.21 & 2.35 & 2.41 & 2.54 \\
\hline 8 & 1.96 & 2.10 & 2.16 & 2.30 & 2.36 & 2.49 & 2.55 & 2.69 & 2.74 & 2.88 \\
\hline 10 & 2.31 & 2.44 & 2.50 & 2.64 & 2.69 & 2.83 & 2.89 & 3.02 & 3.08 & 3.21 \\
\hline 15 & 3.14 & 3.26 & 3.34 & 3.47 & 3.53 & 3.66 & 3.73 & 3.84 & 3.92 & 4.05 \\
\hline 20 & 3.98 & 4.12 & 4.18 & 4.31 & 4.37 & 4.50 & 4.56 & 4.70 & 4.76 & 4.89 \\
\hline 25 & 4.82 & 4.95 & 5.01 & 5.14 & 5.20 & 5.34 & 5.40 & 5.53 & 5.58 & 5.71 \\
\hline 30 & 5.64 & 5.78 & 5.84 & 5.98 & 6.04 & 6.17 & 6.22 & 6.35 & 6.40 & 6.54 \\
\hline 35 & 6.47 & 6.61 & 6.67 & 6.81 & 6.87 & 7.00 & 7.05 & 7.18 & 7.23 & 7.37 \\
\hline 40 & 7.30 & 7.44 & 7.50 & 7.64 & 7.70 & 7.83 & 7.88 & 8.01 & 8.06 & 8.20 \\
\hline 45 & 8.12 & 8.27 & 8.33 & 8.46 & 8.52 & 8.66 & 8.71 & 8.84 & 8.90 & 9.03 \\
\hline 50 & 8.96 & 9.09 & 9.14 & 9.28 & 9.34 & 9.48 & 9.54 & 9.68 & 9.73 & 9.86 \\
\hline 60 & 10.62 & 10.76 & 10.82 & 10.95 & 11.00 & 11.13 & 11.19 & 11.32 & 11.37 & 11.49 \\
\hline 70 & 12.28 & 12.41 & 12.46 & 12.59 & 12.65 & 12.77 & 12.82 & 12.95 & 13.01 & 13.15 \\
\hline 80 & 13.93 & 14.06 & 14.11 & 14.24 & 14.29 & 14.42 & 14.47 & 14.60 & 14.66 & 14.80 \\
\hline 90 & 15.58 & 15.71 & 15.76 & 15.89 & 15.94 & 16.07 & 16.12 & 16.25 & 16.30 & 16.43 \\
\hline 100 & 17.13 & 17.36 & 17.33 & 17.55 & 17.54 & 17.73 & 17.74 & 17.91 & 17.93 & 18.09 \\
\hline
\end{tabular}

Figure 6 shows the plot of dimensionless drawdown, $s_{D}{ }^{*}$, vs. the skin factor, $S_{F}$ (for dimensionless wellbore storage $C_{D}=10^{5}$ ). For the sake of clarity, only the values $S_{F}=0,20,30$, and 50 are used in Figure 6.

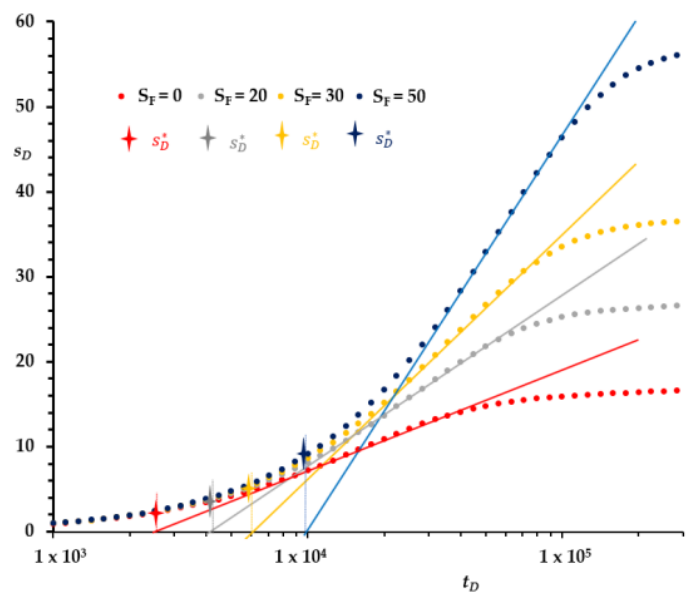

Figure 6. Example of drawdown $s_{D}{ }^{*}$ from graph $s_{D}$ vs. $\log t_{D}\left(\right.$ for $S_{F}=0,20,30,50$, and for $\left.C_{D}=1 \times 10^{5}\right)$.

Figure 7 shows an example of the dependences of dimensionless drawdown, $s_{D}{ }^{*}$, vs. the skin factor, $S_{F}$, for the selected values of $C_{D}$.

Figure 7 shows that the dependences of $s_{D}{ }^{*}$ and $S_{F}$ are a set of parallel straight lines. The equations for the system of straight lines can be expressed by:

$$
s_{D}^{*}=a_{s i} S_{F}+b_{s i}
$$

where coefficients $a_{s i}$ and $b_{s i}$ for all straight lines (as shown in Figure 7) were evaluated by means of the least squares method. Based on Figure 7 and Table 1, it follows that these coefficients are a function of the dimensionless skin factor, $S_{F}$. The dependence $a_{s i}=\mathrm{f}\left(S_{F}\right)$ and also the dependence. 


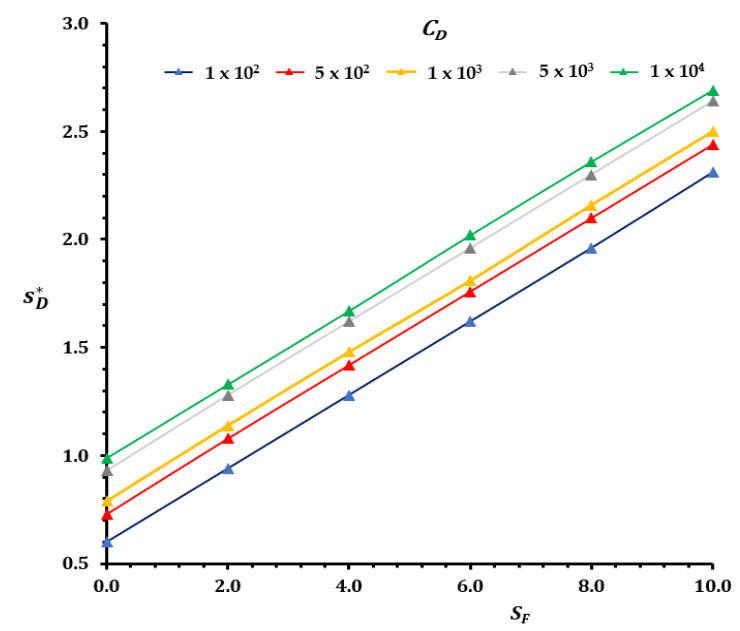

Figure 7. Dependence $s_{D}{ }^{*}$ vs. skin factor, $S_{F}$, for values of $C_{D}\left(1 \times 10^{2}, 5 \times 10^{2}, 1 \times 10^{3}, 5 \times 10^{3}\right.$, and 1 $\left.\times 10^{4}\right)$ and $S_{F}(0,2,4,6,8$, and 10$)$.

$b_{s i}=\mathrm{f}\left(S_{F}\right)$ were evaluated by similar equations, as stated in [52]:

$$
a_{s i}=\frac{n \sum_{i=1}^{n} S_{F i} s_{D i}^{*}-\sum_{i=1}^{n} S_{F i} \sum_{i=1}^{n} s_{D i}^{*}}{n \sum_{i=1}^{n} S_{F i}^{2}-\left(\sum_{i=1}^{n} S_{F i}\right)^{2}} .
$$

For all values of the dimensionless wellbore coefficient, $C_{D}$, the coefficient $a_{s i}$ was constant and equal to 0.166 .

The values of coefficient $b_{s i}$ for the given values of dimensionless wellbore storages, $C_{D}$, were evaluated in the same way as those in [52]. The equation for the solved dependence has the form:

$$
b_{s i}=\frac{\sum_{i=1}^{n} S_{F i}^{2} \sum_{i=1}^{n} s_{D i}^{*}-\sum_{i=1}^{n} S_{F i} \sum_{i=1}^{n} S_{F i} s_{D i}^{*}}{n \sum_{i=1}^{n} S_{F i}^{2}-\left(\sum_{i=1}^{n} S_{F i}\right)^{2}} .
$$

The evaluated values of coefficient $b_{s i}$, using Equation (29) for dimensionless $C_{D}$ drift, are shown in Table 2.

Table 2. $b_{s i}$ coefficients for the dimensionless wellbore coefficient, $C_{D}$.

\begin{tabular}{ccc}
\hline $\mathbf{N}$. & $\boldsymbol{C}_{\boldsymbol{D}}$ & $\boldsymbol{b}_{\boldsymbol{s}}$ \\
\hline 1 & $1.0 \times 10^{2}$ & 0.6448 \\
2 & $5.0 \times 10^{2}$ & 0.7690 \\
3 & $1.0 \times 10^{3}$ & 0.8420 \\
4 & $5.0 \times 10^{3}$ & 0.9754 \\
5 & $1.0 \times 10^{4}$ & 1.0375 \\
6 & $5.0 \times 10^{4}$ & 1.1689 \\
7 & $1.0 \times 10^{5}$ & 1.2325 \\
8 & $5.0 \times 10^{5}$ & 1.3644 \\
9 & $1.0 \times 10^{6}$ & 1.4272 \\
10 & $5.0 \times 10^{6}$ & 1.5581 \\
11 & $1.0 \times 10^{7}$ & 1.6195 \\
\hline
\end{tabular}

Based on a plot, the dependence of the coefficient $b_{S} i$ vs. the logarithm of the dimensionless wellbore storage coefficients represented by $C_{D}$, from Table 2 was found to be linear (see Figure 8). 


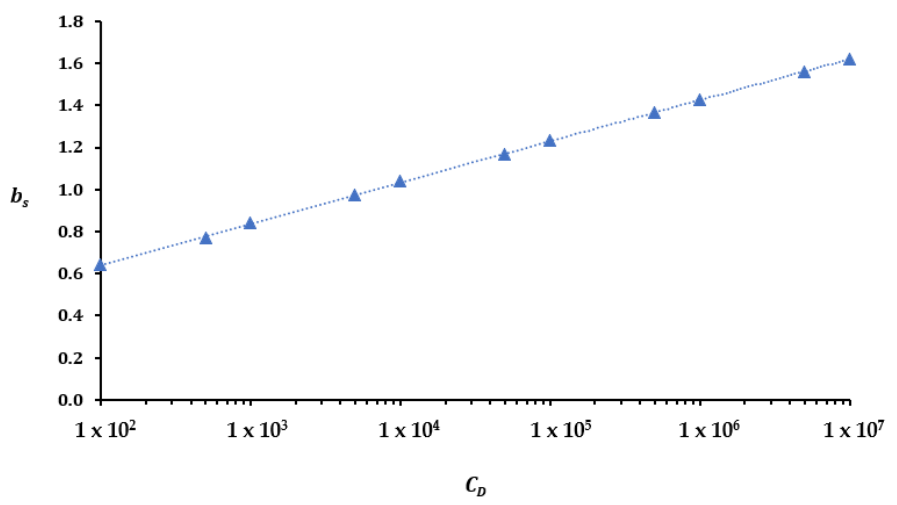

Figure 8. Graph of $b_{s i}$ coefficients vs. $\log C_{D}$.

The equation expressing a linear relationship $b_{s}$ vs. $\log C_{D}$ has the form:

$$
b_{S}=b_{1 S} \log C_{D}+b_{2 S}
$$

To evaluate the coefficients $b_{1 S}$ and $b_{2 S}$, we use a modified version of Equations (28) and (29):

$$
\begin{gathered}
b_{1 s}=\frac{n \sum_{i=1}^{n}\left(\log C_{D}\right)_{i} b_{s i}-\sum_{i=1}^{n}\left(\log C_{D}\right)_{i} \sum_{i=1}^{n} b_{s i}}{n \sum_{i=1}^{n}\left(\log C_{D}\right)_{i}^{2}-\left(\sum_{i=1}^{n}\left(\log C_{D}\right)_{i}\right)^{2}} \\
b_{2 s}=\frac{\sum_{i=1}^{n}\left(\log C_{D}\right)_{i}^{2} \sum_{i=1}^{n} b_{s i}-\sum_{i=1}^{n}\left(\log C_{D}\right)_{i} \sum_{i=1}^{n}\left(\log C_{D}\right)_{i} b_{s i}}{n \sum_{i=1}^{n}\left(\log C_{D}\right)_{i}^{2}-\left(\sum_{i=1}^{n}\left(\log C_{D}\right)_{i}\right)^{2}} .
\end{gathered}
$$

The values of $b_{1 S}$ and $b_{2 S}$ were evaluated via Equations (31) and (32):

$b_{1 S}=0.1908, b_{2 S}=0.2681$.

After substituting the calculated coefficients into Equation (27), we obtain the final equation for $s_{D}{ }^{*}$ in the form:

$$
s_{D}^{*}=0.166 S_{F}+0.1908 \log C_{D}+0.2681 .
$$

After substituting the dimensionless parameters Equations (6) and (7) into Equation (33) and expressing the coefficient of additional resistances, we obtain the resulting equation for the skin factor in the form:

$$
S_{F}=\frac{1}{0.166}\left(\frac{2 \pi T s^{*}}{Q}-0.1908 \log \frac{C}{2 \pi r_{W}^{2} S}-0.2681\right)
$$

Field Test: Rehabilitation of the Dug S-V well—Veselí Nad Lužnicí

We applied the derived method for evaluating mechanical rehabilitation and calculating the value of the skin factor from the early-portion of pumping tests at the well S-Vwell, which is situated near the village of Veselí nad Lužnicí (see Figure 9).

Pumping tests were carried out before rehabilitation, after rehabilitation, and to verify the well's ageing after one year of exploitation of the well. The pumping tests were carried out at a constant pumped rate under an unsteady flow regime.

The dug well S-V has an inside diameter of $3 \mathrm{~m}$. The well depth is $10 \mathrm{~m}$, and the position of the water level below the terrain is approximately $1.9 \mathrm{~m}$. For the geological profile, see Figure 10. 


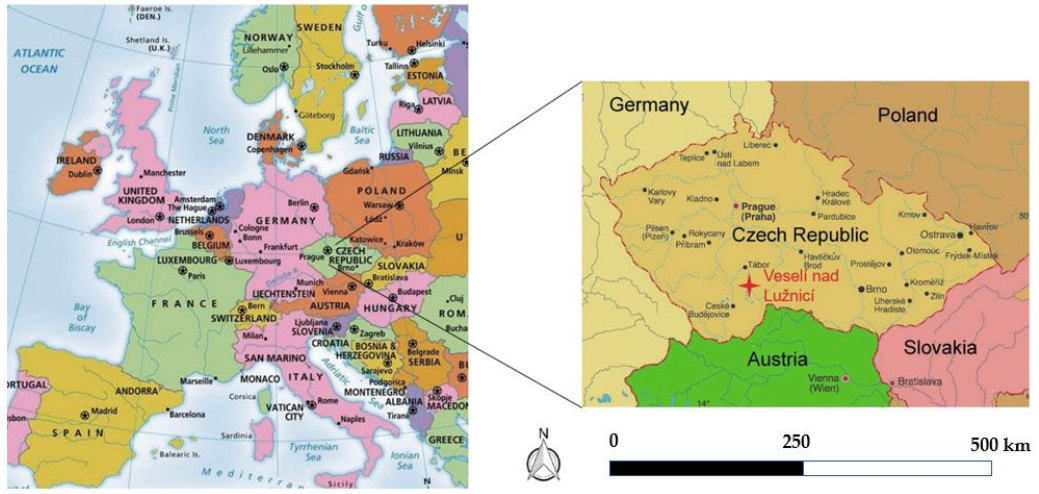

Figure 9. Location of the well S-V near Veselí/n. Lužnicí.

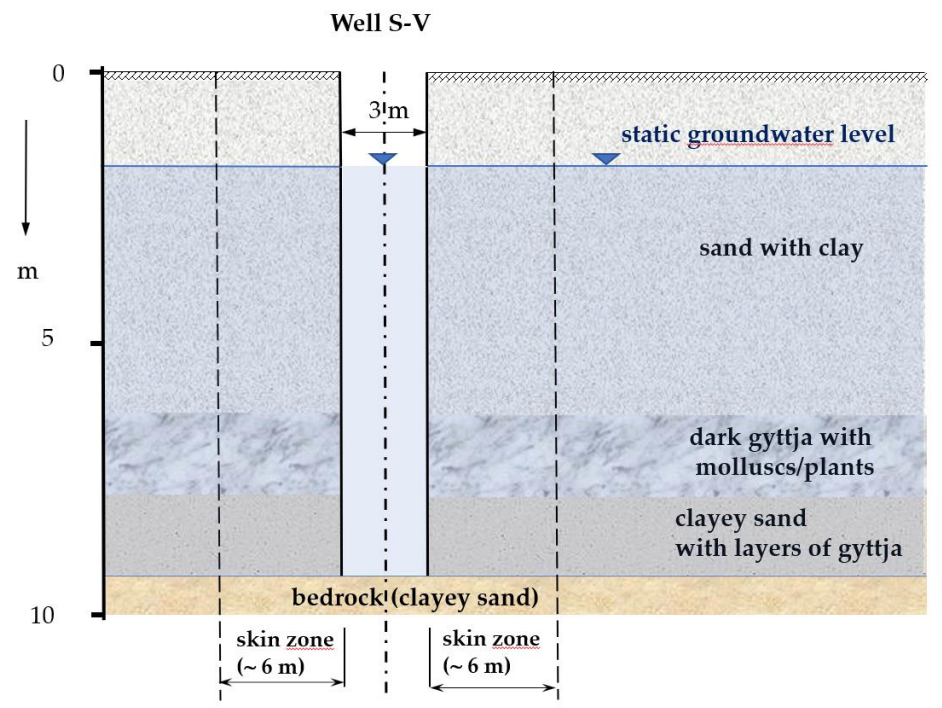

Figure 10. Cross-section of the S-V well with geology [61].

Based on the long-term pumping tests, when the late portion evaluable by the Cooper-Jacob semilogarithmic approximation [2] was reached, the hydraulic parameters of the aquifer were evaluated with a coefficient of transmissivity $T=0.00715 \mathrm{~m}^{2} \mathrm{~s}^{-1}$ and a storage coefficient $S=0.074$.

Before rehabilitation, we created observation wells R-1 to R-4, which were $80 \mathrm{~mm}$ in diameter with average depths of 9.0, and wells P-1 to P-6, which were $50 \mathrm{~mm}$ in diameter, with the same depth of $9.0 \mathrm{~m}$ (see Figure 11).

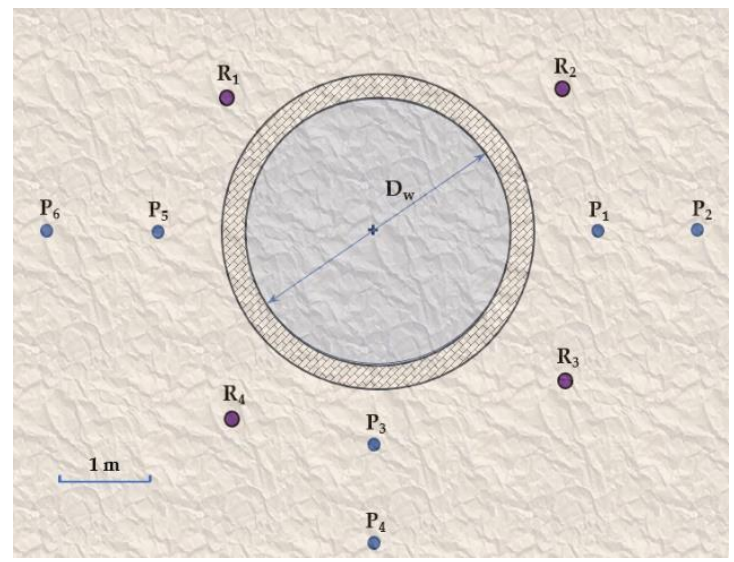

Figure 11. Pumping $S-V$ well with the location of the observation boreholes, $P_{i}$ and $R_{i}$ 
For the pumping tests, the submersible pump was placed approximately $1.5-2.0 \mathrm{~m}$ above the bottom of the well, with a displacement Js of $80 \mathrm{~mm}$, an elbow with a sampling cock, and a water meter Js of $80 \mathrm{~mm}$, with spool and waste piping from chemlon hoses. The waste pipe was connected outside the protective zone of the water source to the adjacent sandy part. For the evaluation of the pumping test, the observation well $\mathrm{P}_{7}$ was located outside the area affected by additional resistance with an internal diameter of $50 \mathrm{~mm}$. The shape of the graph of the pumping test before rehabilitation showed that the yield of the well was very low (a large increase on the well's shell subsequently emerged from the evaluation). The casing of the well had a large number of inlet openings, and the inspection showed that the inlet openings were, for the most part, clogged with sand, clay, and pebbles, or were overgrown with hard increments. The environment behind the borehole of the well (according to observation of the water level in the casing boreholes) was rounded (low permeability). Based on these findings, the following rehabilitation procedure was performed. First, the blasting of observation boreholes $P_{i}$ and $R_{i}$ was carried out using cleaning heads. Thereafter, pressure regeneration was carried out using the observation wells, which had an effect on the well surroundings. After the water level was lowered to approximately $2.5 \mathrm{~m}$ above the bottom, mechanical cleaning of the overgrown inlet holes was carried out in the well. At the same time, pressure regeneration of the surroundings of the well was carried out using pressure surges in the observation wells made especially for this purpose, and the impurities were drained from the inside of the well.

The pumping tests were performed such that they could be evaluated by methods of the unsteady flow regime-i.e., the time shape of the drawdown in the well S-V and in the observation well P6 was measured while pumping a constant amount of water from the well. The starting level was about $1.9 \mathrm{~m}$ from the well edge. The pumping test before rehabilitation lasted $180 \mathrm{~min}$ at a constant pumping rate of $3.35 \mathrm{~L} / \mathrm{s}$, and the drawdown in the well was $s_{w}=4.5 \mathrm{~m}$. After rehabilitation, a pumping test of $240 \mathrm{~min}$ at a pumping rate of $3.7 \mathrm{~L} / \mathrm{s}$ was performed, and the drawdown at the end of pumping was $s_{w}=1.03 \mathrm{~m}$. One year after the rehabilitation was performed, a pumping test of $75 \mathrm{~min}$ at a constant pumped rate of $3.52 \mathrm{~L} / \mathrm{s}$ was carried out to determine the development of the well's ageing. The drawdown at the end of the pumping test was $\mathrm{s}_{\mathrm{w}}=1.29 \mathrm{~m}$ (see Table 3). During the pumping tests, water samples were taken for complete chemical and bacteriological analyses (alkalinity, acidity, $\mathrm{pH}$, and fixation of iron (II)), which were performed on site.

Table 3 shows the pumping tests before rehabilitation (a), after rehabilitation (b), and one year after rehabilitation (c).

Table 3. Pumping tests at S-V well in Veselí nad Lužnicí before rehabilitation (a), after rehabilitation (b), and one year after rehabilitation (c).

\begin{tabular}{|c|c|c|c|c|c|c|c|}
\hline & & (a) & & (b) & & & (c) \\
\hline N. & Time $t(s)$ & Drawdown $s(m)$ & Time $t(s)$ & Drawdown $s(m)$ & N. & Time $t(s)$ & Drawdown $s(m)$ \\
\hline 1. & 130 & 0.02 & 30 & 0.01 & 1. & 60 & 0.08 \\
\hline 2. & 215 & 0.04 & 45 & 0.025 & 2. & 120 & 0.13 \\
\hline 3. & 240 & 0.05 & 60 & 0.03 & 3. & 180 & 0.16 \\
\hline 4. & 300 & 0.08 & 90 & 0.045 & 4. & 300 & 0.21 \\
\hline 5. & 420 & 0.14 & 150 & 0.08 & 5. & 600 & 0.305 \\
\hline 6. & 560 & 0.20 & 180 & 0.09 & 6. & 900 & 0.4 \\
\hline 7. & 800 & 0.28 & 240 & 0.115 & 7. & 1200 & 0.47 \\
\hline 8. & 900 & 0.33 & 300 & 0.135 & 8. & 1800 & 0.62 \\
\hline 9. & 1180 & 0.46 & 600 & 0.25 & 9. & 2700 & 0.75 \\
\hline 10. & 1800 & 0.67 & 900 & 0.34 & 10. & 3600 & 0.84 \\
\hline 11 & 2700 & 1.02 & 1200 & 0.415 & 11 & 4500 & 0.9 \\
\hline 12. & 3600 & 1.25 & 1500 & 0.475 & 12. & 9000 & 1.09 \\
\hline 13. & 5600 & 1.76 & 1800 & 0.54 & 13. & 15,000 & 1.18 \\
\hline 14. & 7200 & 2.20 & 2100 & 0.585 & 14. & 27,000 & 1.25 \\
\hline 15. & 10,800 & 2.78 & 2700 & 0.65 & 15. & 50,000 & 1.27 \\
\hline 16. & 14,200 & 3.14 & 3600 & 0.72 & 16. & 80,000 & 1.285 \\
\hline 17. & 20,000 & 3.51 & 5400 & 0.82 & & & \\
\hline 18. & 30,000 & 3.91 & 7200 & 0.875 & & & \\
\hline
\end{tabular}


Table 3. Cont

\begin{tabular}{|c|c|c|c|c|c|c|c|}
\hline & \multicolumn{2}{|r|}{ (a) } & \multicolumn{2}{|r|}{ (b) } & & \multicolumn{2}{|r|}{ (c) } \\
\hline N. & Time $t(s)$ & Drawdown $s(m)$ & Time $t(s)$ & Drawdown $s(m)$ & N. & Time $t(s)$ & Drawdown $s(m)$ \\
\hline 19. & 44,000 & 4.15 & 10,800 & 0.955 & & & \\
\hline 20. & 70,000 & 4.32 & 14,400 & 0.98 & & & \\
\hline 21. & 100,000 & 4.41 & 25,000 & 1.01 & & & \\
\hline 22. & 200,000 & 4.47 & 40,000 & 1.02 & & & \\
\hline 23. & 400,000 & 4.50 & 72,000 & 1.03 & & & \\
\hline
\end{tabular}

The following graphs (Figure 12a-c) show the values of drawdown over time for the pumping tests. Based on the semilogarithmic dependencies, the drawdown vs. the logarithm of time was subtracted by the magnitude of the drawdown for the intersection time of the first straight line (whose slope is $i_{z}$ ) segment with the timeline axis (see Figure 5).
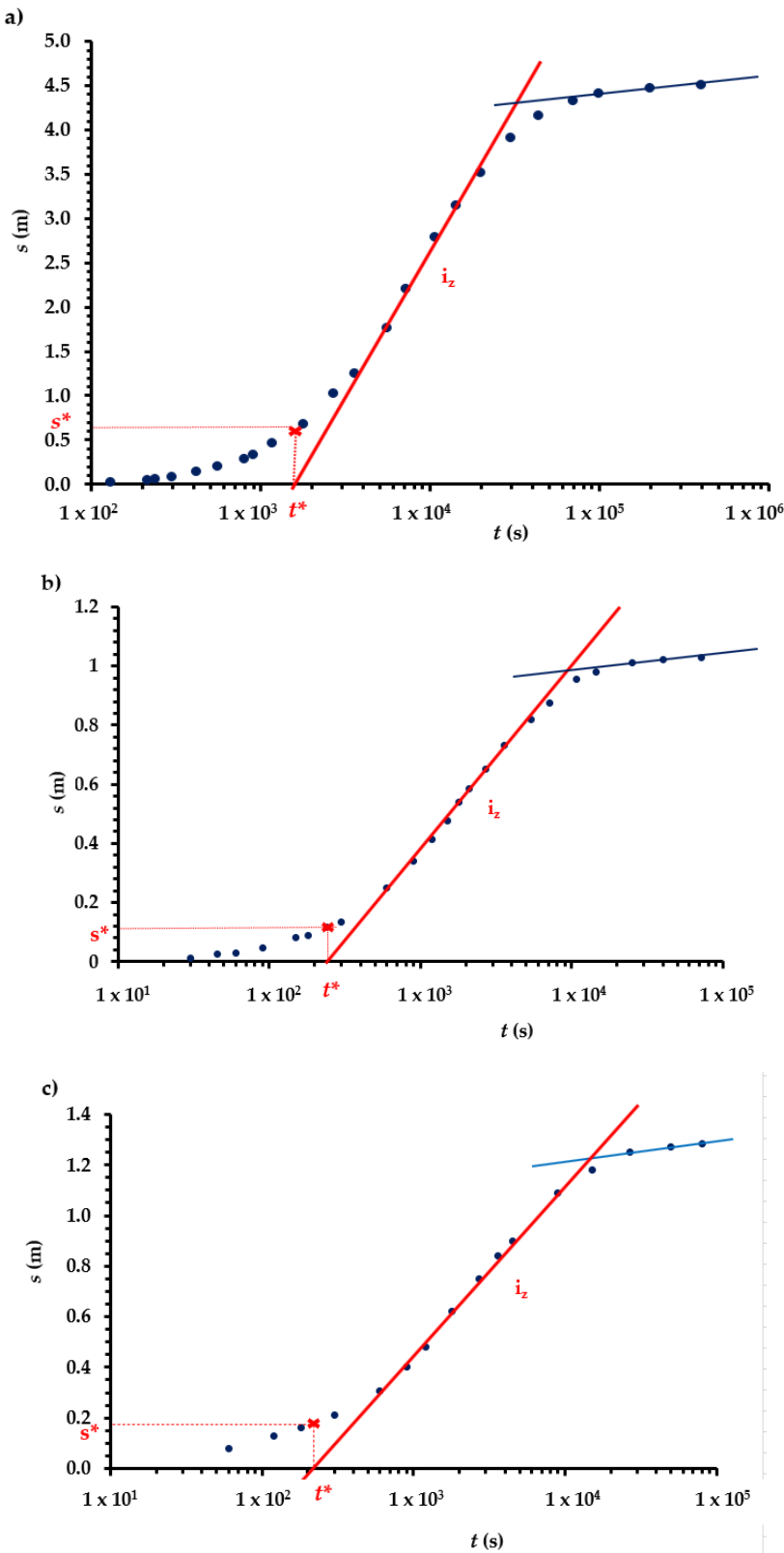

Figure 12. Semilogarithmic graphs of the pumping tests on the S-V well (a) before rehabilitation, (b) after rehabilitation, and (c) one year after rehabilitation. 
Using the derived relationship (Equation (34)), the skin factor values were evaluated, and the drawdown caused by the additional resistance (according to van Everdingen [21]) was determined. This drawdown corresponds to the additional drawdown at a steady flow to the well. The skin factor values were also evaluated using the Cooper-Jacob semilogarithmic method, since second straight lines were achieved in all three pumping tests. Skin factors were determined using Equation (16).

The pumping tests showed that the rehabilitation resulted in a reduction of the skin factor from 48 to 6.8 , which indicates the effectiveness of the selected rehabilitation intervention. Furthermore, to evaluate the ageing of the well, a pumping test was carried out after one year of operation (i.e., one year after the rehabilitation). The skin factor increased from 6.8 to by 10.8 (see Table 4), which proved the deterioration of the well's condition after a year of operation post-regeneration.

Table 4. Results of evaluating the skin factor and additional drawdown-S-V well.

\begin{tabular}{cccc}
\hline & Before Rehabilitation & After Rehabilitation & 1 Year after Rehabilitation \\
\hline Pumping rate, $Q\left(\mathrm{~m}^{3} \cdot \mathrm{s}^{-1}\right)$ & 0.00335 & 0.0037 & 0.00352 \\
Pumping test duration $(\mathrm{s})$ & 400,000 & 72,000 & 80,000 \\
$\mathrm{~s}^{*}(\mathrm{~m})$ & 0.62 & 0.135 & 0.18 \\
New method (Equation (34)) & 47 & 6.8 & 10.8 \\
Cooper-Jacob method & 51 & 7.9 & 12 \\
$\quad$ (Equation (16)) & 8.4 & 15 & 11.1 \\
Difference (\%) & 3.51 & 0.56 & 0.85 \\
Additional drawdown $s_{\text {skin }}$ & & & \\
(Equation (12)) & & & \\
\hline
\end{tabular}

\section{Discussion and Conclusions}

In this paper, we derived a correlation of the dimensionless drawdown for the intersection time $t_{D}{ }^{*}$ of the first straight-line (see Figure 3) of the pumping test in a semilogarithmic graph as a function of the dimensionless wellbore storage, $C_{D}$, and the skin factor, $S_{F}$ (Equation (12)). The derivation was undertaken by applying an approximate solution of the partial differential equation using dimensionless parameters for the symmetrical radial flow problem in an infinite confined aquifer with a constant thickness to the fully penetrating well, pumped with a steady flow rate. The solution was obtained by using the Laplace transform in conjunction with the Stehfest algorithm 368, the approximate method for the numerical inversion of the solution in Laplace space. The skin factor, $S_{F}$, was evaluated from the early portion of pumping test data (the part of the pumping test before the Cooper-Jacob semilogarithmic straight-line was achieved) by means of Equation (34).

The skin factor from the semilogarithmic plot $\left(s_{w}\right.$ vs. $\left.\log t\right)$ of the early portion of the pumping test can be evaluated without using type curve matching. This new procedure is particularly useful when the early-time slope of the first straight-line has been observed. The usefulness of the derived correlation $\mathrm{s}^{*}$ (vs. $S_{F}$ and $C_{D}$ ) has been demonstrated in the field example through the evaluation effect of mechanical rehabilitation at a S-V well (Veselí nad Lužnicí). The validity of this new method was checked by comparing the skin factor calculated by the new method with the Cooper-Jacob semilogarithmic method (Equation (16)) (see Table 1). We evaluated the differences between the skin factor determined from Equation (34) and that determined from Equation (16). Comparing these skin factors demonstrates that the estimate of $S_{F}$ is in fair agreement with the other values. For the field example, the agreement is surprisingly good. The differences ranged between $7 \%$ and $12 \%$ (Table 4 ).

If the pumping test is too short to observe the Cooper-Jacob semilogarithmic straight line, then the derived method is applicable for evaluation of the skin factor; all other parameters must be known, but the pumping test should run long enough that $s_{w}$ vs. $\log t$ can fully develop into "the first straight line" on the semilogarithmic plot. This method may be used when other techniques do not provide satisfactory answers or if the late-time portion of the pumping test is missing and the Cooper-Jacob method or type curve cannot be used. For the application-derived procedure, the storage coefficient and transmissivity of the aquifer must be known, but to evaluate the effects of rehabilitation on the 
well and accurately control age, this procedure is sufficient. We applied the stated method to several other evaluations of rehabilitation wells. In all instances, the results of the Cooper-Jacob method were as good as those in the previous field example comparisons. The differences were a maximum of $25 \%$ (in groundwater, this is very good agreement). However, the derived procedure presented in this paper is not proposed to replace the current methods used in groundwater hydraulics and petroleum engineering. To evaluate the skin factor from the initial pumping test section, it is necessary to record a decrease in the water level in the well at sufficiently short intervals immediately from the start of pumping. It is advisable to select a monitoring interval of $1 \mathrm{~s}$ until the beginning of the first straight line in the semilogarithmic chart, and then it is possible to observe the reduction in time steps of 5-10 s. This is very important for the application of the method. By correctly applying the derived method and correctly determining the first straight line (the first straight line can be determined in almost all instances), the intersection time of the first slope with the log $t$ axis can be determined with a high degree of confidence. The application of this method eliminates the main problem of the type curve method because lines of different types are often so similar that it is very difficult, and often impossible, to find conformity with the actual pump test curve. For this reason, quantitative information cannot be obtained with the same degree of accuracy as information obtained via calculations using conventional Cooper-Jacob approximations. Due to the cost of extended pumping tests, the modern trend has been towards the development of hydrodynamic tests for the pertinent analysis for early-period data for information obtained prior to the usual straight-line of the well test [5]. These data can be analyzed using the "derived method" for economic or practical reasons. The method derived here contributes to the possible evaluation of the skin factor. The advantage of this method is that it can be used in cases where the application of other methods is difficult or even impossible.

This new technique is applicable to the interpretation of ground water-pumping tests. When deriving the groundwater flow, dimensionless parameters were used. The results could also be applied also to petroleum areas if the dimensionless parameters from [10] are used.

- Dimensionless pressure:

$$
p_{D}^{*}=\frac{k h}{141.2 q B \mu} \Delta p^{*}
$$

- Dimensionless intersection time:

$$
t_{D}^{*}=\frac{0.000264 k t^{*}}{\phi \mu c_{t} r_{w}^{2}}
$$

- Dimensionless wellbore storage:

$$
C_{D}=\frac{5.615 C}{\phi c_{t} h r_{w}^{2}}
$$

where $k$ is the permeability (md), $h$ is the formation thickness ( $\mathrm{ft}), q$ is the flow rate (STB/D), $B$ is the formation volume factor (RB/STB), $\mu$ is viscosity (cp), $\Delta p$ is the pressure change (psi), $\phi$ is the porosity, $c_{t}$ is the total compressibility $\left(\mathrm{psi}^{-1}\right), r_{w}$ is the wellbore radius (ft), and $C$ is the wellbore storage coefficient (STP/psi).

With these dimensionless parameters for petroleum engineering, Equation (33) is:

$$
p_{D}^{*}=0.166 S_{F}+0.1908 \log C_{D}+0.681 .
$$

From this equation, the skin factor $S_{F}$ can be evaluated.

It should be noted that the derived method for skin factor determination is not intended as a substitute for other procedures but as a complementary solution providing application possibilities even when some methods cannot be used.

Author Contributions: Conceptualization, D.K. and P.P.; methodology, P.P.; software, P.P.; validation, D.K. and P.P.; investigation, P.P.; resources, D.K.; writing-original draft preparation, D.K. and P.P.; writing-review and editing, P.P. and D.K.; project administration, P.P. All authors have read and agreed to the published version of the manuscript. 
Funding: This research was funded by Technology Agency of the Czech Republic, grant number TH02030421 "ULTRA-technology for pumping well rehabilitation based on ultrasound emission".

Conflicts of Interest: The authors declare no conflict of interest.

\section{References}

1. Theis, C.V. The relation between the lowering of the piezometric surface and the rate and duration of discharge of a well using ground-water storage. Trans. Am. Geophys. Union 1935, 16, 519-524. [CrossRef]

2. Cooper, H.H.; Jacob, C.E. A generalized graphical method for evaluating formation constants and summarizing well-field history. Trans. Am. Geophys. Union 1946, 27, 526-534. [CrossRef]

3. Bourdet, D. Well test analysis: The use of advanced interpretation models. Handb. Pet. Explor. Prod. 2002, 3 , 1-426. [CrossRef]

4. Lee, J. Well Testing. In SPE Textbook Series Vol. 1; Society of Petroleum Engineers: Richardson, TX, USA, 1982; p. 159. ISBN 978-089520-317-5.

5. Horne, R.N. Modern Well Test Analysis: A Computer Aided Approach, 4th ed.; Alto, P., Ed.; Petroway, Inc.: Palo Alto, CA, USA, 1995; p. 185. ISBN -0-9626992-09.

6. Kresic, N. Hydrogeology and Groundwater Modeling, 2nd ed.; CRC Press, Taylor and Francis: Boca Raton, FL, USA, 2007; ISBN 13 978-0849333484.

7. Watlton, W.C. Aquifer Test Modeling, 1st ed.; CRC Press: Boca Ralton, FL, USA, 2007; p. 240, ISBN-13: 978-1-4200-4292-4.

8. Batu, V. Aquifer Hydraulics: A Comprehensive Guide to Hydrogeologic Data Analysis; John Wiley \& Sons: New York, NY, USA, 1998.

9. Kruseman, G.P.; de Ridder, N.A. Analysis and Evaluation of Pumping Test Data, 2nd ed.; IILRI: Wageningen, The Netherlands, 2008; pp. 1-372.

10. Tongpenyai, Y.; Raghavan, R. The effect of wellbore storage and skin on interference test data. J. Pet. Technol. 1981, 33, 151-160. [CrossRef]

11. Novakowski, K.S. A Composite analytical model for analysis of pumping tests affected by well bore storage and finite thickness skin. Water Resour. Res. 1989, 25, 1937-1946. [CrossRef]

12. Pasandi, M.; Samani, N.; Barry, D.A. Effect of wellbore and finite thickness skin on flow to a partially penetrating well in a phreatic aquifer. Adv. Water Resour. 2008, 31, 383-398. [CrossRef]

13. Papadopulos, I.S.; Cooper, H.H. Drawdown in a well of large diameter. Water Resour. Res. 1967, 3, $241-244$. [CrossRef]

14. Moench, A.F. Transient flow to a large-diameter well in an aquifer with storative semiconfining layers. Water Resour. Res. 1985, 21, 1121-1131. [CrossRef]

15. Chen, C.; Lan, C. A simple data analysis method for a pumping test with skin and wellbore storage effect. Terr. Atmos. Ocean. Sci. 2009, 20,557-562. [CrossRef]

16. Ramey, H.H., Jr. Short-time well test data interpretation in the presence of skin effect and wellbore storage. J. Pet. Technol. 1970, 22, 97-104. [CrossRef]

17. Yeh, H.D.; Yang, S.Y.; Peng, H.Y. A new closed-form solution for a radial two-layer drawdown equation for groundwater under constant-flux pumping in a finite-radius well. Adv. Water Resour. 2003, 26, 747-757. [CrossRef]

18. McKinley, R.M. Wellbore transmissibility from afterflow-dominated pressure buildup data. J. Pet. Technol. 1971, 23, 863. [CrossRef]

19. Kabala, Z.J. Sensitivity analysis of a pumping test on a well with wellbore storage and skin. Adv. Water Resour. 2001, 24, 483-504. [CrossRef]

20. Ramey, H.J.; Agarwal, R.G. Annulus unloading rates as influenced by wellbore storage and skin effect. Soc. Pet. Eng. J. 1972, 12, 453-462. [CrossRef]

21. Van Everdingen, A.F. The skin effect and its influence on the productive capacity of a well. J. Pet. Technol. 1953, 5, 171-176. [CrossRef]

22. Hurst, W. Establishment of skin effect and its impediment to fluid flow into a well bore. Pet. Eng. 1953, 25, B6-B16.

23. Hawkins, M.F., Jr. A note on the skin effect. Trans. Am. Inst. Min. Met. Eng. 1956, 8, 356-357. [CrossRef] 
24. Park, E.; Zhan, H.B. Hydraulics of a finite-diameter horizontal well with wellbore storage and skin effect. Adv. Water Resour. 2002, 25, 389-400. [CrossRef]

25. Barua, G.; Bora, S.N. Hydraulics of a partially penetrating well with skin zone in a confined aquifer. Adv. Water Resour. 2010, 33, 1575-1587. [CrossRef]

26. Jargon, J.R. Effect of wellbore storage and wellbore damage at the active well on interference test analysis. J. Pet. Technol. 1976, 28, 851-858. [CrossRef]

27. Yang, S.Y.; Yeh, H.D. Solution for flow rates across the wellbore in a two-zone confined aquifer. J. Hydraul. Eng. ASCE 2002, 128, 175-183. [CrossRef]

28. Chen, C.S.; Chang, C.C. Theoretical evaluation of non-uniform skin effect on aquifer response under constant rate pumping. J. Hydrol. 2006, 317, 190-201. [CrossRef]

29. Basak, P. Steady non-Darcian seepage through embankments closure. J. Irrig. Drain. Div. ASCE 1979, 102, 435-443. Available online: http://cedb.asce.org/CEDBsearch/record.jsp?dockey=0007101 (accessed on 4 September 2019).

30. Sen, Z. Nonlinear flow toward wells. J. Hydraul. Eng. ASCE 1989, 115, 193-209. [CrossRef]

31. Chu, W.C.; Garcia-Rivera, J.; Raghavan, R. Analysis of interference test data influenced by wellbore storage and skin at the flowing well. J. Pet. Technol. 1980, 32, 623-630. [CrossRef]

32. Agarwal, R.G.; Al-Hussainy, R.; Ramey, H.J. An investigation of wellbore storage and skin effect in unsteady liquid flow: I. Analytical treatment. Soc. Pet. Eng. J. 1970, 10, 279-291. [CrossRef]

33. Earlougher, R.C., Jr.; Kersch, K.H. Analysis of short-time transient test data by type-curve matching. J. Pet. Technol. 1974, 26, 793-800. [CrossRef]

34. Earlougher, R.C., Jr. Advances in well test analysis. Monogr. Ser. Soc. Pet. Eng. AIME 1977, 5, 264. Available online: https://trove.nla.gov.au/version/13397770 (accessed on 24 August 2019).

35. Bourdet, D.; Whittle, T.M.; Douglas, A.A.; Pirard, Y.M. A new set of type curves simplifies well test analysis. World Oil 1983, 196, 95-106. [CrossRef]

36. Gringarten, A.C.; Bourdet, D.P.; Landel, P.A.; Kniazeff, V.J. A comparison between different skin and wellbore storage type-curves for early-time transient analysis. Soc. Pet. Eng. SPE Ann. Technol. C Exh. 1979, 1-16. [CrossRef]

37. Yeh, H.D.; Chang, Y.C. Recent advances in modeling of well hydraulics. Adv. Water Resour. 2013, 51, $27-51$. [CrossRef]

38. Yeh, H.D.; Chen, Y.H. Determination of skin and aquifer parameters for a slug test with wellbore-skin effect. J. Hydrol. 2007, 342, 283-294. [CrossRef]

39. Mashayekhizadeh, M.D.; Ghazanfari, M.H. The application of numerical Laplace inversion methods for type curve development in well testing: A comparative study. Pet. Sci. Technol. 2011, 29, 695-707. [CrossRef]

40. Kuchuk, F.J.; Kirwan, P.A. New skin and wellbore storage type curves for partially penetrated wells. SPE Eval. 1987, 2, 546-554. [CrossRef]

41. Wattenbarger, R.A.; Ramey, H.J. An investigation of wellbore storage and skin effect in unsteady liquid flow: II. Finite difference treatment. Soc. Pet. Eng. J. 1970, 10, 291-297. [CrossRef]

42. Moench, A.F. Specific yield as determined by type-curve analysis of aquifer-test data. Ground Water 1994, 32, 949-957. [CrossRef]

43. Wen, Z.; Huang, H.G.; Zhan, H.B. Non-Darcian flow in a single confined vertical fracture toward a well. J. Hydrol. 2006, 330, 698-708. [CrossRef]

44. Stehfest, H. Algorithm 368: Numerical inversion of Laplace transforms. Commun. ACM 1970, 13, 47-49. [CrossRef]

45. Van Everdingen, A.F.; Hurst, W. The application of the Laplace transformation to flow problems in reservoirs. J. Pet. Technol. 1949, 1, 305-324. [CrossRef]

46. Pech, P.; Novotny, R. Analytical solutions for well drawdown with well losses: 1. Multiple well system near a boundary. J. Environ. Hydrol. 2005, 13, 1-10. Available online: http://www.hydroweb.com/journalhydrology-2005-paper-27.html (accessed on 5 November 2019).

47. Novotny, R.; Pech, P. Analytical solutions for well drawdown with well losses: 2 . Real well near boundary-solution by image well. J. Environ. Hydrol. 2005, 13, 1-7. Available online: http://www.hydroweb.com/jeh/jeh2005/pech2.pdf (accessed on 5 November 2019). 
48. Pech, P. Estimation of a well damage or stimulation. Sci. Agric. Bohem. 2004, 35, 131-134. Available online: https://sab.czu.cz/en/r-8044-archive/r-8064-older-issues/r-11689-04-2004\#i28f1287e11d0452b811e7a4937989a20 (accessed on 22 September 2019).

49. Holub, J.; Pech, P.; Kuraz, M.; Maca, P.; Kahuda, D. Evaluation of a pumping test with skin effect and wellbore storage on a confined aquifer in the Bela Crkva, Serbia. Int. J. Water 2019, 13, 1-11. [CrossRef]

50. Raghavan, R. Well Test Analysis, 1st ed.; PTR Prentice Hall: Englewood Cliffs, NJ, USA, 1993; p. 554.

51. Houben, G.; Treskatis, C. Water Well Rehabilitation and Reconstruction, 3rd ed.; McGraw Hill Professional: Two Penn Plaza, NY, USA, 2007; ISBN 0-07-148651-8.

52. Adebayo, A.R.; Bageri, B.S. A simple NMR methodology for evaluating filter cake properties and drilling fluid-induced formation damage. J. Pet. Explor. Prod. Technol. 2019, 9. [CrossRef]

53. Elkatatny, S.; Jafarov, T.; Al-Majed, A.; Mahmoud, M. Formation Damage Avoidance by Reducing Invasion with Sodium Silicate-ModifiedWater-Based Drilling Fluid. Energies 2019, 12, 485. [CrossRef]

54. Iscan, A.G.; Kok, M.V.; Bagci, A.S. Permeability Reduction Due to Formation Damage by Drilling Fluids. Energy Sources 2007, 29, 851-859. [CrossRef]

55. Ralph, D.E.; Stevenson, J.M. The role of bacteria in well clogging. Water Res. 1995, 29, 365-369. [CrossRef]

56. Houben, G.J. Iron oxide incrustations in Wells-Part 1: Genesis, mineralogy and geochemistry. Appl. Geochem. 2003, 18, 927-939. [CrossRef]

57. Patel, M.C.; Singh, A. Near Wellbore Damage and Types of Skin Depending on Mechanism of Damage. In Proceedings of the Society of Petroleum Engineers SPE International Conference and Exhibition on Formation Damage Control, Lafayette, LA, USA, 24-26 February 2016. [CrossRef]

58. Pech, P. Determination of the skin factor in the early portion of an aquifer test. J. Environ. Hydrol. 2003, 11, 1-9. Available online: http://www.hydroweb.com/jeh/jeh2002/pech.pdf (accessed on 5 November 2019).

59. Abramowitz, M.; Stegun, I.A. Handbook of Mathematical Functions with Formulas, Graphs and Mathematical Tables, 10th ed.; Government Printing: Wahington, DC, USA, 1972; p. 470.

60. Yang, S.Y.; Yeh, H.D. Laplace-domain solutions for radial two-zone flow equations under the conditions of constant-head and partially penetrating well. J. Hydraul. Eng. ASCE 2005, 131, 209-216. [CrossRef]

61. Hošek, J.; Pokorný, P.; Prach, J.; Šída, P.; Kř́žek, M. Fossil thermokarst in South Bohemia (Czech Republic). Geosci. Res. Rep. 2018, 51, 131-139. Available online: http://www.geology.cz/img/zpravyvyzkum/fulltext/27_ Hosek_180903.pdf (accessed on 5 September 2019).

(C) 2020 by the authors. Licensee MDPI, Basel, Switzerland. This article is an open access article distributed under the terms and conditions of the Creative Commons Attribution (CC BY) license (http://creativecommons.org/licenses/by/4.0/). 